IJBPAS, December, Special Issue, 2021, 10(12): 564-575

ISSN: 2277-4998

International Journal of Biology, Pharmacy and Allied Seiences (IJBPAS)

'A Bridge Between Caboratory and Qendo'

Www.ijbpas.com

\title{
LIFE STYLE DISORDERS: STHAULYA W.S.R. TO OBESITY
}

\section{ISHWARAYYA S MATHAPATI $1^{1^{*}}$, MANU R $^{2}$, JYOTHI R H $^{3}$, PARAPPAGOUDRA M $^{4}$}

1: Ph.D. Scholar, Department of Kayachikitsa Parul University Limda, Waghodiya Vadodara391760, Gujarat (India)

2: Professor \& H.O.D.Department of Kayachikitsa Parul University Limda, Waghodiya Vadodara-391760, Gujarat (India)

3: Asst. Professor, Dept. of Shalakya Tantra, S.S.R.A.M.C\&H, Inchal, Belagavi, Karnataka

4: Assistant Professor Department of Panchakarma, Parul University Limda, Waghodiya

Vadodara-391760, Gujarat (India)

*Corresponding Author: Ishwarayya S Mathapati; E Mali: dr.ishwar.mathapati@gmail.com

Received $9^{\text {th }}$ May 2021; Revised 10 ${ }^{\text {th }}$ July 2021; Accepted 29 ${ }^{\text {th }}$ Aug. 2021; Available online $15^{\text {th }}$ Dec. 2021

https://doi.org/10.31032/IJBPAS/2021/10.12.1049

ABSTRACT

Obesity is most prevalent in middle-age. Women are more prone to be obese than men. Most of the world's population live in countries where overweight and obesity kills more people than underweight. At present Gujarat is the second largest state in India regarding prevalence of obesity and heart disease. The condition in which there is a increase in body weight beyond the limitation of skeletal and physical requirements as the result of excessive accumulation of body fat is called Obesity. According to WHO in the year 2016, more than 1.9 billion adults, 18 years and older, were overweight. So the main objective of this review article is to find out the effective treatment modalities of Ayurveda like Shodhana, Shamana and Pathya for the management of Sthaulya (Obesity).

Keywords: Sthaulya, Obesity, Hyperlipidaemia, Vrikshamla, Apatarpana, Shodhana,

Shamana, Charaka, Bhavaprakasha Nighantu, Ayurveda

Definition:

Obesity is an increase in body weight beyond the limitation of skeletal and physical requirements as the result of excessive accumulation of body fat. ${ }^{1}$ 
Prevalence of Obesity: Obesity is most prevalent in middle-age. Women are more prone to be obese than men. At present Gujarat is the second largest state in India regarding prevalence of obesity and heart disease. $^{2}$

Some recent WHO global estimates follow.

The worldwide prevalence of obesity is nearly tripled between 1975 and 2016. In 2016, there were $39 \%$ of adults aged 18 years and over, were overweight. About $13 \%$ of the world's adult population were obese. $^{3}$

\section{INTRODUCTION:}

Person's life who is suffering from SthaulyaRoga becomes miserablypathetic because of the Dosha like hampered physical activity, hampered sexual life,extreme lassitude, proneness to dangerous diseases, above all decreased life span. It is widely acknowledged that obesity has emerged as an epidemic in developed countries. It continues to be an issue of great concern. Also, we are now facing the problem of obesity in worldwide, affecting wealthy and middle income people.

\section{Types of obesity:}

In simple the Obesity can be classified as:

1. Exogenous obesity: A common form due to excessive intake of food. The distribution of fat is uniform, although somewhat excessive under the chin (double chin) and the abdomen. This is also termed as simple obesity or primary Obesity.

2. Endogenous or glandular obesity: when being overweight is the primary complaint, an endocrine disorder is seldom the cause. This is also known as secondary Obesity. ${ }^{4}$

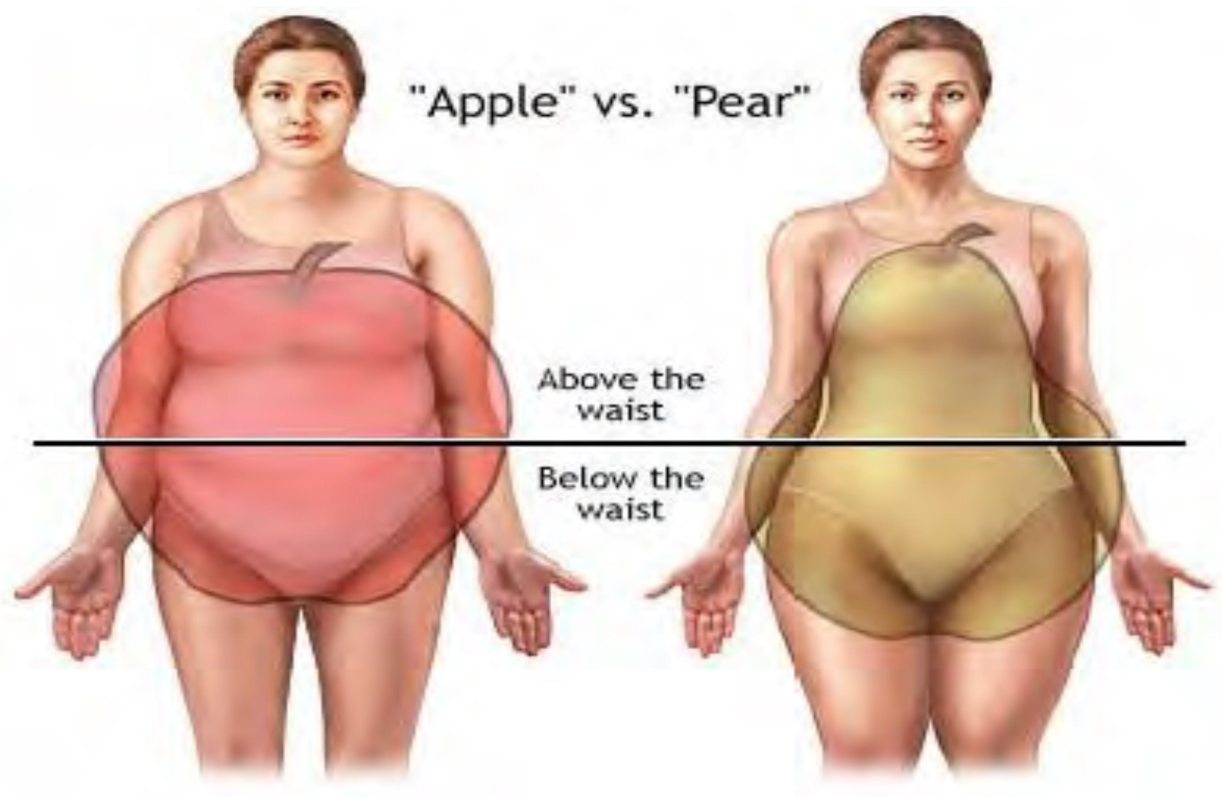

$\underline{\text { Figure } 1}$ 
Causes:

1) Aharaja Nidana

2) Viharaja Nidana

1. AharajaNidana:

- Consumption of foods enhancing phlegm.

- Consuming food articles of sweet taste in excess (madhuroannarasah).

- Consumption of food before digestion of previously consumed food. (Ama).

- Excess intake of fat contained or fatty food articles and oils, ghee, etc-oily substances (prayahsnehath). ${ }^{5}$

- Obesity or Hyperlipidaemia is the excess Accumulation of lipids (especially plasma lipids) in the body, leading various acute or chronic condition.

- Though Sthaulya doesn't refer as Hyperlipidaemia, but there are all the chances that both these conditions coexist or one may predispose other. So it is quite essential to know about lipids and Hyperlipidaemia.

- Ayurveda classics have also referred that

prayahasnehatmedahapravardha yet", implying the fact that excess sneha is responsible for excess production of Meda and such excessively produced Meda causing avarodha or avarana of other. Dhatu leading to Medoroga or Sthaulya Lakshana as well as Upadrava. Here we can link the vikruti which is explained in Ayurveda with present modern knowledge about lipids.

\section{ViharajaNidana:}

1. Avyayama(Non practice of physical exercise).

2. Divasvapna (Sleeping in day time).

3. Sedentary life style. ${ }^{6}$

Table 1: Showing Illustrating various SthaulyaNidana.

\begin{tabular}{|c|c|c|}
\hline \multirow{4}{*}{ Aharaja } & $\begin{array}{c}\text { Santarpana Guna } \\
\text { Pradhana Ahara }\end{array}$ & $\begin{array}{c}\text { Guru, Manda, Seeta, Snigdha, Slakshna, Sandra, Sthula, Picchila and } \\
\text { Abhishyandhiahara etc, }\end{array}$ \\
\cline { 2 - 3 } & Rasa Pradhana Ahara & Madhura rasa \\
\cline { 2 - 3 } & Dravyapradhana Ahara & Navanna, Gorasa, Dadhi (curd), Mamsa, Atimeda, Gaudika, Varuni. \\
\cline { 2 - 3 } & Ahara Krama & Adhyashana, Atisampoorna, Atimatraahara \\
\hline Viharaja & \multicolumn{2}{|c|}{ Avyayama, Shayyasanasukha, Ayavaya, Diwaswapna } \\
\hline Manasika & \multicolumn{2}{|c|}{ Achinta, Arati, Harshanityatwa } \\
\hline Anya & \multicolumn{2}{|c|}{ Beejaswabhava, Vaidyakruta. } \\
\hline
\end{tabular}

\section{Pathogenies of Obesity:}

According to modern science: Adult onset obesity is characterized predominantly by adipose cell hypertrophy with minimum hyperplasia. Apart from increase in size of normal depots eg. the subcutaneous tissue, the omentum, the retoro-peritoneal tissues and epicardium, adipose tissue in obesity may be extended to the tissues, where it is normally absent. The three main 
components in pathogenesis of obesity are excessive lipid deposition, diminished lipid mobilization and diminished lipid utilization. Excessive lipid deposition is due to increased food intake, hypothalamic lesions, adipose cell hyperplasia or hyper lipogenesis. Excessive intake of food in the form of Carbohydrates, Proteins and Fats, the metabolic process in our body lastly converts these all into fats and later they get stored in fat depots. Diminished lipid metabolism is due to decrease in lipolytic hormones, ageing, defective lipid oxidation, defective thermogenesis or inactivity, abnormality of autonomous innervating thyroxine and adrenaline which stimulates mobilization of unsaturated fatty acids from adipose tissue, increases lipid deposition and ultimately leads to obesity. ${ }^{7}$

\section{According to Ayurveda:}

\section{Samanya Samprapti of Sthaulya Roga:}

Due to the indulgence in various Nidana the Ama, Anna, Rasa is produced and which acquires the Madhuarataratva and this along with Atisneha will produce Meda, in turn Atisthaulya in the body. More over the Medadhatu will be responsible for Margavrodha of rest of the Dhatu and resulting in improper nourishment of them.

Due to the over accumulation of Meda, Vatavrudhi occurs in Kosta leading to the Atisandhukshana of Jataregni. By that, the consumed food will be digested rapidly and makes the person to crave for food. If at all due to any reason food is not received in time may lead to various Pathologies. But repeated consumption of food in turn helps in Medavrudhi only. So such vicious cycle continues leading to various Laxana and complications in Sthaulya (Obesity). 
Flowchart Showing the Illustrating Sthaulya (Obesity)Samprapti Schematically

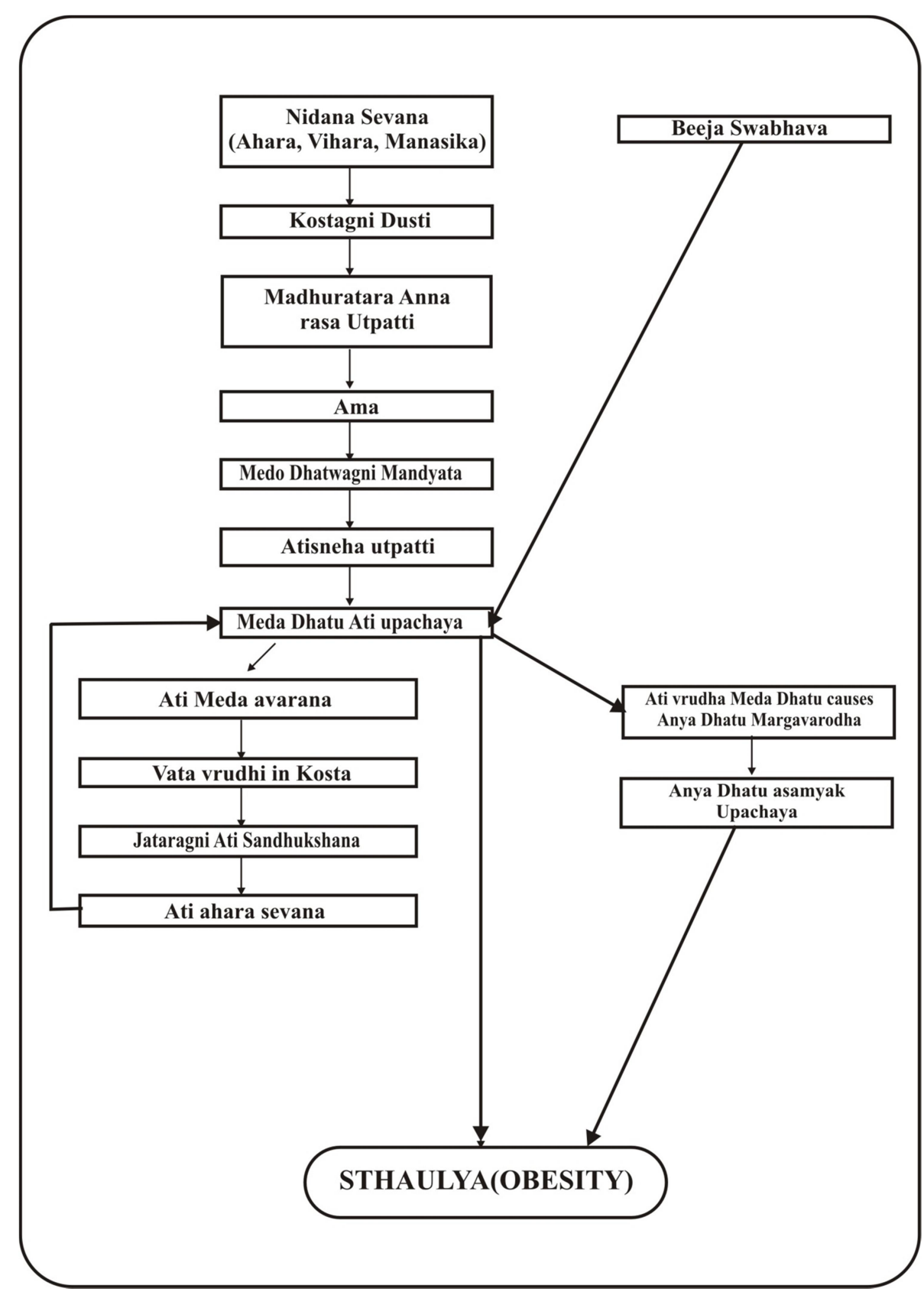

Symptoms:

1) Movements or activities of body in routine become hampered, with loss of enthusiastic activity of human body showing laziness in any bodily action;

2) Feeling difficulty in performance of sexual intercourse (krcchravyavaya) by showing physical inactivity in absence of sexual act to full extent.

3) Persons suffers from debility in general (dourbalyam).

4) Body of persons gives foul smell (dehadourgandhyam)-this is 


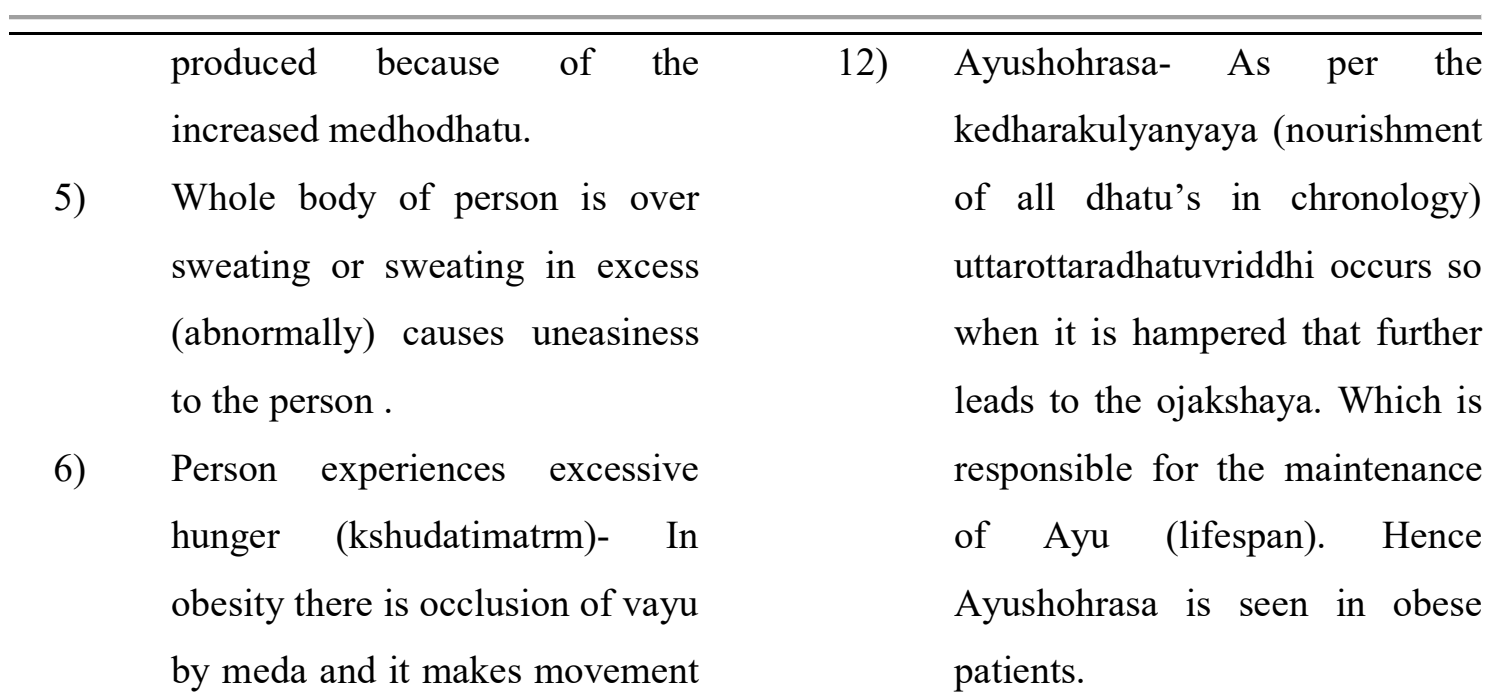

in koshta and while moving there

it activates or generates agni to higher mark and makes absorption fast of ingested food.

7) Person remains over thirsty (pipasatiyogha) $)^{8}$ - Because of the increased digestive power, Vitiated vata and undigested fats occurs in the patient.

8) Breathlessness, thirst, excessive sleep, lethargy.

9) Exertional dyspnea.

10) Kanthaghurghura, Glani, Alpaprana (lesser vitality and weak in general)

11) Alpamithuna (incapability insufficiency in performing coitus) i.e. Krucchravyavayat. Because of the mandhata of medadhatwagni there will be the less production of shukradhatu. Hence the person experiences difficulty in sexual act.

\section{Complication of Obesity:}

The following are the list of complications of Obesity ${ }^{9}$ :

口 Type 2 diabetes mellitus

व Hypertension

Stroke

口 Hyperlipidaemia

- Coronary heart diseases

a Gall stones

口 Arthritis of hip, knee and foot

Varicose veins

a Breathlessness

口 Sleep apnoea

a Infertility

๑ Hirsutism

口 Abdominal hernia

口 Depression

- Cancers of breast, endometrium, ovaries etc.

\section{Management Therapy:}

Annapana (food) which is vatagna, shleshmahara (alleviates the phlegm) and medhohara (fat reducing) should be given to obese person, in 
accordance to general principle of therapies recommended for the management of obesity.

\section{Treatment}

\section{Dietary control:}

It is largely depends on a reduction in calorie intake. The most common diets allow a daily intake of approximately $4200 \mathrm{k}$ joules (1000 kcal), although this may need to be nearer $6300 \mathrm{k}$ joules (1500 kcal) for someone engaged in physical work. Persons must realize that prolonged dieting is necessary for large amounts of fat to be lost. A permanent change in eating habits is required to maintain the low weight. It is relatively easy for most people to lose the first few kilograms.

The general aim of any dietary regimen or protocol is to lose approximately $1 \mathrm{~kg}$ per week. Weight loss will be greater initially owing to accompanying protein and glycogen breakdown and consequent water loss. After 3-4 weeks, incremental weight loss may be very small because only adipose tissue is broken down and there is no accompanying water loss. Person must understand the principles of energy intake and expenditure. The best results are obtained in educated, well-motivated person.

The diet should contain adequate amount of each nutrient. A diet of
1000 kcal per day should be made up of approximately 100 gm of carbohydrate, 50 $\mathrm{gm}$ of protein and $40 \mathrm{gm}$ of fat. The carbohydrate should be in the form of complex carbohydrate such as vegetable and fruit rather than simple sugars. Alcohol provides $7 \mathrm{kcal}$ per gm, should be discouraged. A balanced diet, is of much greater value and safer than any of the slimming regimens.

\section{Exercise:}

An increase in exercise will increase energy expenditure and should be encouraged - provided there is contraindication - since weight is usually not achieved without exercise. Regular exercise along with proper diet is must.

\section{Behavioural Modification:}

Behaviour therapy is a term, which covers wide variety of treatment at approaches. This therapy is based on an attempt to produce permanent changes in behaviour by involving the patient in his own management, guides the patients to observe his current life style, eating habit, activities etc, and encourage changing it. The programs includes monitoring intake, modifying causes that signal "in appropriate eating", modifying the act of eating itself, increasing exercise and selfreward for more appropriate behaviour.

The following are the different type of Chikitsa which are applied to treat Obesity in Ayurveda. 
$>$ SantarpanajanyaVyadhi Chikitsa (Treatment for excessive malnutrition)

$>$ Guru cha Atarpana (Treament which act on vata without increasing Kapha)

> LanghanaChikitsa(Fasting treatment)

$>$ Pathyapathya with special importance to nidanaparivarjana. (Diet and exercise control)

- Santarpanajanya Vyadhi Chikitsa:

Procedures like Vamana

(Emesis Therapy), Virechana (Purgation therapy), Raktamokshana (Blood-letting), Vyayama (Exercise), Upavasa (Fasting) and Swedana (Fomentation) are been explained for all the disease, which are originated because of over-nourishment and sedentary life style. Apart from the above, other medicines like Vrikshamla Churna (Powder) along with luke warm water, honey with Haritakichurna (powder), Rooksha Annapana (food), Triphaladiquatha (decoction), Musthadiquatha and Kustadichoorna are also advised to tackle with Obesity.

\section{- Guru cha A-tarpana:}

This is one of the basic line of treatment, which is mainly adopted, in the selection criteria dietary drugs for fatty person. Meaning of "Guru Cha
Atarpana" is that those drugs which are heavy for digestion and having the AtarpanaGuna. As the digestion power is at optimum level, hence diet which is heavy for digestion should be prescribed and at the same time these drugs should not nourish the body. Drugs having above properties are Vrikshamla (Garcinia Cambogia), Priyangu (Aglaiaelaeagnoidea), Shyamaka (Oroxylumindicum), Yava (Hordeumvulgare), Kodrava (Paspalumscrobiculatum), Mudga (Vignaradiata), Kulatha (Dolichosbifloru), Patola (Trichosanthesdioica), Madhudaka (Madhucalongifolia) etc.

\section{- Langhana Chikitsa}

$$
\text { AcharyaCharaka is }
$$

explained about 10 different types of Langhana, which can broadly classify as

1. Shodhana rupi langhana (Treatment of detoxification)

2. Shamana rupi langhana (Treatment of internal medication)

\section{Pathyapathya (Do's and Don'ts )}

This is the unique contribution of Ayurveda and explained for almost all diseases. It plays an important role as much as of medicine and it is rightly mentioned that "if one follow Do's, than there is no need of medicine and if not there is no use of therapeutic measures". 


\begin{tabular}{|c|c|}
\hline \multicolumn{2}{|c|}{ Table 2: Showing Ahararupi Pathya - Apathya (diet do's and don'ts) for Obesity } \\
\hline Pathya (DO'S) & Apathya (DON'TS) \\
\hline Yava (Barley), Kodrava (Kodo millet) & $\begin{array}{c}\text { Godhuma (Wheat), Navanna (new harvested crops), } \\
\text { shali (Rice) }\end{array}$ \\
\hline $\begin{array}{c}\text { Mudga (Mung ), Rajamasha (Cow peas), Kulatha (Horse } \\
\text { gram), Chanaka (Chick peas) }\end{array}$ & Masha (Black gram), Tila (Seasamum) \\
\hline Patola (Wild snake guard) & Madhuraphala (sweat fruits) \\
\hline $\begin{array}{c}\text { Takra(Butter milk), Madhu (Honey), ushnodhaka (Warm } \\
\text { water), Sarshapa Taila (Mustard oil), Arista, Asava, } \\
\text { JeernaMadya (Alcohol and wines) }\end{array}$ & $\begin{array}{c}\text { Dugda (Milk), navaneeta (Butter), dadhi (Curd) } \\
\text { Rohita matsya (Rohu fish) }\end{array}$ \\
\end{tabular}

Table 3: Showing Vihararupi Pathya-Apathya (Routine DO'S and DON'TS) for obesity

\begin{tabular}{|c|c|}
\hline Pathya & Apathya \\
\hline Srama (Physical effort) & Divaswapna (Day sleep) \\
Jagarana (Awakening at night) & Avyayama(Non practice of physical exercise) \\
Vyayama (Exercise) & Avyavaya ( Avoid sexual indulgence ) \\
Chintana (Stress) & Sukha shayya ( Sedentary life style) \\
& Nitya harsha (Avoiding active work) \\
& Achintana (Avoiding stress) \\
& Sheetala jalapana (Avoid cold water) \\
\hline
\end{tabular}

\section{Treatments Indicated in obesity:}

They are:
a. Vamana (Emesis therapy)
b. Virechana (Purgation therapy)
c. LekhanaBasti (Enema therapy)
d. Udwartana
e. Yoga and life style modification.

\section{a. Vamana (Emesis therapy)}

Vamana karma is one of the classical Bio-purificatory therapy which eliminates the morbid material, like vitiated Dosha, metabolic waste, unwanted excessive accumulated substance from the body through the Oral route. It is specific for Kapha Dosha which belongs to the category of MedoDhatu (Fats), there by having its direct effect on Fat tissue which may be one of the reason for reduction in lipid levels, further Vamana also corrects Pitta Dosha to moderate extent indirectly improves functioning of liver which plays an important role in the lipid metabolism. Hence this may be the second reason for reduction of lipid levels. Vamana karma being bio-purification process helps in mobilisation of peripheral fat, which subsequently gets eliminated through liver.

\section{b. Virechana (Purgation therapy)}

This is the choice of treatment for Pittajavikara and also for Pitta sthanagata-Vatavikara as its action is seen in Pakvashaya also in the form of Vatanulomana (downward movement of gases) as vata dosh is causative factor of obesity. Hence this can be adoptable in the obesity. Virechana therapy throws out accumulated toxic metabolites, ensures 
patency of micro and macro channels, optimizes absorption and assimilation of nutrients and pharmacological agents, permits the transport of ions and molecules through the cell membrane, and facilitates the desired pharmacokinetics of the curative remedies administered thereafter.

\section{c. LekhanaBasti: (Enema therapy)}

To check the vitiated Vata that is present all over the body, classical texts have explained about Basti therapy, as it acts at the root level of Vata. In the context of Obesity, Among all varieties of Basti, LekhanaBasti (scrapping basti) stands in the first place to tackle the condition.

\section{d. Udwartana (Powder massage)}

Dry herbal powders massage is known as Udwartana. It is for reducing excess cellulite and fat accumulated under the skin. Udwartana also tones up the skin and provides strength to the body. Other benefits may include that improvement in skin complexion, skin exfoliation, stress relief and relaxation.

\section{e. Yoga and lifestyle \\ Yoga acts on the leptin}

level. Leptin decreases the appetite, increases energy expenditures. Improving mood, and reducing stress, which may help reduce food intake; and Allowing individuals to feel more connected to their bodies, leading to enhanced awareness of satiety and the discomfort of overeating.
Conflict of interest: None.

REFERENCES:

[1] https://www.ncbi.nlm.nih.gov/pmc/ $\underline{\text { articles/PMC1880830/ }}$

[2] Jo willey, A nation of fatties; Big appetite for snacks is fuelling an obesity crisis, warns experts

[3] https://www.who.int/newsroom/fact-sheets/detail/obesity-andoverweight

[4] Physical Diagnosis Vakil\&Golwalla

[5] Charaka, carakasamhita, Agnivesh"s treatise refined and annotated by caraka and redacted by drudabala, with chakrapanidatta edited by yadavajitrikamjiacharya edition 2009 page no 116, Sutra sthana $1^{\text {st }}$ chapter, Chaukhambha Publications, 2011

[6] Bhavamishravirachita

Bhavaprakasha commentary by Dr. K C Chunekar, Edited by Dr. G S Pandey Chaukamba Bharati Academy Varanasi 2004. Bhavaprakash Nighantu Amradiphalavarga explained in his $6^{\text {th }}$ chapter Shloka No. 148 and 149.

[7] Dr. Hemant Bhardwaj and Dr. Omprakash Sharma, Understanding The Sthaulaya In Modern Era: A Review Article.

[8] Charaka, Charakasamhita, Agnivesh"s treatise refined and 
annotated by caraka and redacted by drudabala, with chakrapanidatta edited by yadavajitrikamjiacharya, Sutra sthana $23^{\text {rd }}$ and $27^{\text {th }}$ chapter Phala Varga, Shloka 151 edition 2009.

[9] Cardiovascular Disease \& Diabetes, http: //www heart. org/HEARTORG /Conditions / More/Diabetes/WhyDiabetesMatter s/Cardiovascular-Disease Diabetes UCM_ 313865_ Article. jsp/\#.WMpfT2-GPIU

[10] Caraka, carakasamhita, Agnivesh"s treatise refined and annotated by caraka and redacted by drudabala, with chakrapanidatta edited by yadavajitrikamjiacharya edition 2009 page no 116, Sutra sthana $21^{\text {st }} \quad$ chapter, Ashtoninditiyaadhyaya, Chaukhambha Publications,2011

[11] A. Bhartiya, J. P. Aditya and L. Kant, Nutritional And Remedial Potential Of An Underutilized Food Legume Horsegram (Macrotylomauniflorum): A Review, The Journal of Animal \& Plant Sciences, 25(4): 2015, Page: 908-920 ISSN: 1018-7081

[12] Q. Ashton, Action, Phd General editor Obesity: New Insights for the Healthcare Professional: 2013 Edition, https://books.google.co.in/books?i $\mathrm{d}=6 \mathrm{~S} 9 \mathrm{GXX} 3 \mathrm{IN} 28 \mathrm{C} \&$ source $=\mathrm{gbs}$ navlinks_s

[13] Smith KN, Queenan KM, Thomas W, Fulcher RG, Slavin JL., J Am Coll. Nutr. Physiological effects of concentrated barley beta-glucan in mildly hypercholesterolemic adults.

https://www.ncbi.nlm.nih.gov/pub med/188385332008

Jun;27(3):434-40.

[14] Johnson W. McRorie, Jr, What to Look for and How to Recommend an Effective Fiber Therapy Evidence-Based Approach to Fiber Supplements and Clinically Meaningful Health Benefits, Part 2, Nutr Today, 2015 Mar; 50(2): 90-97.Published online 2015 Mar 26. doi: 10.1097/NT.0000000000 000089, PMCID: PMC4415970

[15] Laban K. Rutto, Yixiang Xu, Elizabeth Ramirez, and Michael Brandt, Mineral Properties and Dietary Value of Raw and Processed Stinging Nettle (Urtica dioica L.), International Journal of Food Science, Volume 2013 (2013), Article ID 857120, 9 pages http: // dx. doi. Org /10 $.1155 / 2013 / 857120$ 
[16] Plant-Derived Agents with AntiGlycation Activity Mariela Odjakova, Eva Popova, Merilin Al Sharif and Roumyana Mironova Additional information is available at the end of the chapter http://cdn.intechopen.com/pdfs$\mathrm{wm} / 39450$.

[17] Jeanie Lerche Davis Weight-Loss Tip: Add Extra Calcium to a LowFat Diet, http: // www. webmd.com/diet/news/20000417/ca lcium-low-fat-diet\#1

[18] Neethu S Kumar, Arun S Nair, Anju M Nair, Megha Murali Pharmacological and therapeutic effects of triphala - A literature review, Journal of Pharmacognosy and Phytochemistry 2016; 5(3): 23-27

[19] Brigid McKevith British Nutrition Foundation, London, UK, Nutritional aspects of cereals, https:/www.nutrition.org.uk/attac hments/207_Nutritional\%20aspect s\%20of\%20cereals.pdf

[20] http://www.gnit.ac.in/pdf/emagazine-to-print-finalupdated.pdf 